STAINU Purworejo: Jurnal As Sibyan Jurnal Kajian Kritis Pendidikan Islam

\title{
PERAN GURU DALAM MENINGKATKAN KEDISIPLINAN SISWA SD NEGERI TANJUNGANOM BANYUURIP KABUPATEN PURWOREJO
}

\author{
Dina Suprihatiningrum, S.Pd \\ STAINU Purworejo \\ Email: dinasupri8@gmail.com \\ Siti Anisatun Nafi'ah, M.Pd \\ STAINU Purworejo \\ Email: anisnafiah14@gmail.com \\ Roikhatul Janah, M.Pd \\ STAINU Purworejo \\ Email: roikhatuljanah30@gmail.com
}

\begin{abstract}
The Role of Teachers in Improving Student Discipline at SD Negeri Tanjunganom Banyuurip, Purworejo Regency. This study aims to determine the teacher's strategy in improving the discipline of students at SD Negeri Tanjunganom and to find out the obstacles and supporters in improving the discipline of students at SD Negeri Tanjunganom. This research uses qualitative research methods, which relies on humans as the main data collection tool which will produce descriptive data in the form of written data or oral data from the people being observed. The method used by researchers is by interview, observation and documentation. The results showed that first, in instilling and improving student discipline, teachers can use various strategies, namely; Making teachers as role models, Performing the process of habituation, Delivering directly to children, Giving understanding to children, Application of various rules by the teacher, Imposing sanctions or warnings for violators, Teaching children about the importance of obeying a rule. Second, the obstacles in improving the discipline of SD Negeri Tanjunganom include; The condition of the student itself, the condition of the parents, the family background, the teacher's time with the students. Third, the supporting factors in increasing discipline, among others; Schools, Facilities, Teachers, Students and Parents' Attention.
\end{abstract}

Keywords: Teacher's role, disicipline, students.

\begin{abstract}
Abstrak
Peran Guru dalam Meningkatkan Kedisiplinan Siswa SD Negeri Tanjunganom Banyuurip Kabupaten Purworejo. Penelitian ini bertujuan untuk mengetahui strategi guru dalam meningkatkan kedisiplinan siswa SD Negeri Tanjunganom dan mengetahui kendala dan pendukung dalam meningkatkan kedisiplinan siswa SD Negeri Tanjunganom. Penelitian ini menggunakan metode penelitian kualitatif, yaitu mengandalkan manusia sebagai alat pengumpul data utama yang akan menghasilkan data deskriptif berupa data tertulis atau data lisan dari orang-orang yang diamati. Metode yang digunakan peniliti adalah dengan
\end{abstract}


STAINU Purworejo: Jurnal As Sibyan

Jurnal Kajian Kritis Pendidikan Islam

Vol 4 No 1 Januari - Juni 2021

dan Manajemen Pendidikan Dasar

Homepage: https://ejournal.stainupwr.ac.id/

Email: sibyan.stainupwrj@gmail.com

E-ISSN: : 2599-2732

wawancara, observasi dan dokumentasi. Hasil penelitian menunjukan bahwa pertama, dalam menanamkan dan meningkat kedisiplinan siswa, guru dapat menggunakan berbagai strategi antara; Menjadikan guru sebagai suritauladan, Melakukan proses pembiasaan, Penyampaian secara langsung kepada anak, Pemberian pengertian kepada anak, Penerapan berbagai aturan oleh guru, Pemberian sanksi atau peringatan bagi yang melanggar, Pengajaran kepada anak tentang pentingnya mematuhi sebuah aturan. Kedua, kendala dalam meningkatkan kedisiplinan SD Negeri Tanjunganom antara lain; Kondisi siswa itu sendiri, Kondisi orang tua, Latar belakang keluarga, Waktu guru dengan siswa. Ketiga, Faktor pendukung dalam meningkatkan kedisiplinan antara lain; Sekolah, Fasilitas, Guru, Siswa dan Perhatian orang tua.

\section{Kata Kunci: Peran Guru, Kedisiplinan, Siswa}

\section{A. PENDAHULUAN}

Disiplin adalah tindakan yang menunjukkan perilaku tertib dan patuh pada berbagai ketentuan yang berlaku.1 Disiplin pada anak dapat mencangkup pengajaran bimbingan atau dorongan yang dilakukan orang tua pada anaknya, menerapkan disiplin pada kepada anak bertujuan agar anak belajar sebagai makhluk social. Sekaligus, agar anak mencapai pertumbuhan serta perkembangan yang optimal.2

Disiplin hakikatnya adalah pernyataan sikap mental individu maupun masyarakat yang mencerminkan rasa ketaatan, kepatuhan yang didukung oleh kesadaran untuk menunaikan tugas dan kewajiban dalam rangka pencapaian tujuan.3 Dengan tingkat kedisiplinan siswa yang tinggi diharapkan siswa dapat memperoleh hasil belajar yang optimal. Semakin tinggi tingkat kedisiplinan siswa, maka akan semakin baik hasil belajar yang diraihnya. Dengan mendisiplinkan siswa, kita sebenarnya membantu mereka mengembangkan tanggung jawab dan kendali diri.4

Kedisiplinan memiliki banyak fungsi dalam berbagai bidang kehidupan termasuk dalam proses belajar. Fungsi kedisiplinan dalam kegiatan belajar siswa

\footnotetext{
${ }^{1}$ Aulina. Choirun Nisah, "Penanaman Disiplin Pada Anak Usia Dini”, Pedagogia, Volume 2 Nomor 1, Februari 2017, Hlm.38

${ }^{2}$ Direktorat Pembinaan Pendidikan Anak Usia Dini Direktorat Jendral Pendidikan Anak Usia Dini Nonformal dan Informal Kementrian Pendidikan Nasional Tahun 2011, Hlm. 7 Hlm. 20

${ }^{3}$ Ekosiswoyo, Rasdi dan Rachman, Manajemen Kelas, (Semarang: IKIP Semarang Press, 2000),

${ }^{4}$ Khalsa, Sri Nam S. Pengajaran Disiplin dan Harga Diri. (Jakarta: PT Indeks, 2008), Hlm. 71
} 
STAINU Purworejo: Jurnal As Sibyan

Jurnal Kajian Kritis Pendidikan Islam

Vol 4 No 1 Januari - Juni 2021

dan Manajemen Pendidikan Dasar

Homepage: https://ejournal.stainupwr.ac.id/

Email: sibyan.stainupwrj@gmail.com

E-ISSN: : 2599-2732

yaitu untuk membentuk karakter siswa yang memiliki komitmen dan tanggung jawab yang tinggi untuk mencapai tujuan belajarnya sehingga mengaktifkan dan mengendalikan dirinya untuk melaksanakan tugas dan kewajibannya sebagai siswa. $^{5}$

Guru berperan sangat penting dalam membembentuk peserta didik memiliki pengetahuan, ketrampilan, dan berkarakter. Kedisiplinan diperlukan dalam mewujudkan sumber daya manusia yang memiliki pengetahuan, ketrampilan, dan berkarakter. Dalam pengajarannya, kinerja guru dapat mewujudkan kedisiplinan yang dapat menjadi pedoman siswa sesuai dengan standar yang berlaku di sekolah. Pelaksanaan kedisiplinan diperlukan untuk mencapai tujuan pendidikan yang efektif dan efisien. Sarana untuk menciptakan peserta didik yang berkualitas salah satunya adalah faktor kedisiplinan, dan kemampuan para guru untuk mewujudkan peserta didik yang berkualitas dapat ditingkatkan melalui sarana pendidikan.

Sebagai pengajar, pendidik, dan pembimbing, maka diperlukan adanya berbagai peranan pada diri guru. Peranan guru ini akan senantiasa menggambarkan pola tingkah laku yang diharapkan dalam berbagai interaksinya, baik dengan siswa (yang terutama), sesama guru, maupun dengan staf yang lain. Dari berbagai kegiatan interaksi belajar mengajar, dapat dipandang sebagai sentral bagi peranannya. Sebab baik disadari atau tidak bahwa sebagian dari waktu dan perhatian guru banyak dicurahkan untuk menggarap proses belajar mengajar dan berinteraksi dengan siswanya. ${ }^{6}$

Mendisiplinkan peserta didik sangat penting dilakukan secara terus menerus untuk menjadikan sebuah kebiasaan bagi peserta didik. Orang yang memiliki kedisiplinan tinggi akan menjadi orang yang berhasil dalam bidangnya masingmasing, sebaliknya orang-orang yang gagal, umumnya adalah orang yang tidak disiplin.

Syarat dalam pembentukan sikap, perilaku dan tata tertib adalah disiplin. Hal tersebut dapat mengantarkan peserta didik menjadi orang yang sukses dalam

\footnotetext{
${ }^{5}$ Nurur Rohman, Peran Guru dalam Membentuk Sikap Disiplin Siswa Kelas V di MIN Jombang, (Jombang: 2019), Hlm. 45

${ }^{6}$ Sardiman A.M, “Interaksi Motivasi Belajar Mengajar,”. (Jakarta: PT. Raja Grafindo Persada, 2014), Hlm. 137-138
} 
STAINU Purworejo: Jurnal As Sibyan

Jurnal Kajian Kritis Pendidikan Islam

Vol 4 No 1 Januari - Juni 2021

dan Manajemen Pendidikan Dasar

Homepage: https://ejournal.stainupwr.ac.id/

Email: sibyan.stainupwrj@gmail.com

E-ISSN: : 2599-2732

belajar. Disiplin dapat membantu peserta didik dalam bertingkah laku baik disekolah maupun dirumah. Permasalahan dengan lingkungan sekitar dapat diseleseikan sangat dengan sangat mudah oleh peserta didik, dan peraturan yang diterapkan disekolah akan menjadi hal yang mudah untuk dilaksanakan oleh peserta didik jika peserta didik tersebut sudah menanamkan kedisiplinan dalam dirinya.

Dalam mendidik melalui disiplin dengan berbagai pelaksanaan kebiasaan dan pengulangan kegiatan secara rutin dari hari ke hari yang berlangsung tertib. Di dalam kebiasaan dan kegiatan yang dilakukan secara rutin itu, terdapat nilai-nilai atau norma-norma yang menjadi tolok ukur tentang benar tidaknya sesuatu yang dilakukan oleh seseorang. Norma-norma itu terhimpun menjadi aturan yang harus dipatuhi, karena setiap penyimpangan atau pelanggaran, akan menimbulkan keresahan , keburukan, dan kehidupanpun berlangsung tidak efektif atau bahkan tidak efisien. ${ }^{7}$

Sekolah memiliki berbagai aturan yang telah diterapkan oleh guru yang wajib dilaksanakan oleh siswanya. Disiplin dalam sekolah menjadi suatu kewajiban yang harus dilaksanakan oleh seluruh siswa agar dapat tercapai belajar di sekolah. Guru menjadi peran penting dalam menerapkan maupun meningkatkan kedisiplinan siswanya.

Guru juga memiliki peran sebagai suri tauladan dalam pelaksanaan disiplin.Teladan guru sangat berperan dalam menentukan kedisiplinan siswa karena guru dijadikan teladan dan panutan oleh para siswanya. Guru harus memberi contoh yang baik, jujur, adil, serta sesuai kata dengan perbuatan. Dengan teladan guru yang baik, kedisiplinan siswa pun akan ikut baik. Jika teladan guru kurang baik (kurang berdisiplin), para siswa pun akan kurang disiplin.

SD Negeri Tanjunganom merupakan sekolah yang memberi peran penting dalam membentuk kepribadian siswa yang berdisiplin, yang dimana sekolah dapat menjadi penyemangat para siswa memiliki pribadi yang lebih baik di masa depan. Oleh karena itu guru dituntut untuk berusaha serta bertanggung jawab dalam membentuk karakter disiplin siswa dan senantiasa meningkatkan kualitas

\footnotetext{
${ }^{7}$ Ramayulis, Ilmu Pendidikan Islam , (Jakarta: Penerbit Kalam Mulia, 2002), Hlm. 288
} 
STAINU Purworejo: Jurnal As Sibyan

Jurnal Kajian Kritis Pendidikan Islam

Vol 4 No 1 Januari - Juni 2021

dan Manajemen Pendidikan Dasar

Homepage: https://ejournal.stainupwr.ac.id/

Email: sibyan.stainupwrj@gmail.com

E-ISSN: : 2599-2732

pendidikan. Dari latar belakang di atas peneliti ingin melakukan penelitian yang berjudul "Peran Guru Dalam Meningkatkan Kedisiplinan Saswa SD Negeri Tanjunganom Desa Tanjunganom Kecamatan Banyuurip Kabupaten Purworejo".

Berdasarkan latar belakang di atas, maka penulis membatasi pembahasan dengan membuat rumusan masalah sebagai berikut: Bagaimana peran dan strategi guru dalam meningkatkan kedisiplinan siswa di SD Negeri Tanjunganom? Dan Bagaimana kendala dan pendukung dalam meningkatkan kedisiplinan siswa di SD Negeri Tanjunganom?

\section{B. METODOLOGI}

Penelitian ini menggunakan jenis penelitian kualitatif. Adapun pendekatan yang digunakan dalam penelitian ini yaitu pendekatan fenomenologi. Tempat penelitian ini di SD Negeri Tanjunganom kecamatan Banyuurip, Purworejo.

Adapun subjek penelitian dalam penelitian ini adalah para siswa dan guru SD Negeri Tanjunganom Banyuurip. sumber data yang digunakan peneliti adalah berupa foto, catatan, dan dokumen untuk melengkapi data primer. Objek yang digunakan adalah kedisiplinan siswa SD Negeri Tanjunganom Banyuurip Kabupaten Purworejo. Teknik pengumpulan data menggunakan dokumentasi, observasi dan wawancara. Teknik analisis data menggunakan reduksi data, penyajian data dan verifikasi data. Adapun keabsahan data menggunakan teknik triangulasi data.

\section{HASIL DAN PEMBAHASAN}

1. Peran Guru dan Strategi Guru dalam Meningkatkan Kedisiplinan Negeri Tanjunganom

Guru sangat berperan penting dalam menanamkan sikap disiplin kepada siswanya. Guru menjadi sebuah contoh atau suritauladan bagi peserta didik di sekolah. Perilaku disiplin yang dilakukan oleh guru dapat memberikan contoh yang baik kepada siswa. Ada berbagai strategi atau metode yang digunakan guru dalam menanamkan kedisiplinan siswa. Berdasarkan wawancara dengan ibu kepala 
STAINU Purworejo: Jurnal As Sibyan

Jurnal Kajian Kritis Pendidikan Islam

Vol 4 No 1 Januari - Juni 2021

dan Manajemen Pendidikan Dasar

Homepage: https://ejournal.stainupwr.ac.id/

Email: sibyan.stainupwrj@gmail.com

E-ISSN: : 2599-2732

sekolah bahwa penanaman sikap disiplin dapat dilakukan dengan adanya kegiatan pembinaan anak beriman, sholat berjamaah, pendidikan budipekerti yang diselipkan saat pembelajaran maupun kegiatan upacara bendera. ${ }^{8}$ Hal ini sesuai dengan visi dan misi yang ada di SD Negeri Tanjunganom, yaitu visi; Terwujudnya siswa yang taqwa, cerdas, trampil, berbudi pekerti luhur, memiliki jiwa patriotisme yang tinggi, peduli lingkungan. Misi; (1)Meningkatkan ketaqwaan siswa dalam agama melalui pembinaan anak beriman berkepribadian, (2)Meningkatkan kecerdasan dalam ilmu melalui KBM yang terprogram dan terarah, (3)Meningkatkan ketrampilan siswa melalui pembelajaran SBK, (4)Meningkatkan nilai-nilai moral dan akhlak mulia siswa dalam kehidupan sehari-hari melalui pendidikan budi pekerti, (5)Meningkatkan semangat juang dan patriotisme yang tinggi melalui pembelajaran PKN dan IPS.Penanaman sikap disiplin dapat dilakukan melalui berbagai strategi.

Setiap guru memliliki strategi yang berbeda dalam menanamkan kedisiplinan siswanya. Seperti guru kelas kelas I SD Negeri Tanjunganom, beliau menyatakan bahwa strategi yang dilakukan adalah ada penanaman sikap dan karakter yang baik dilakukan setiap hari, ketauladanan dari guru, mengajarkan anak untuk mematuhi aturan baik di rumah maupun di sekolah, dan memberikan sanksi bila anak melanggar aturan. ${ }^{9}$

Hal ini sejalan dengan pendapat guru kelas VI SD Negeri Tanjunganom, strategi yang diterapkan adalah dengan proses pembiasaan. Ketika ada yang berbuat kesalahan akan diberikan sanksi agar ada punishment agar ada efek jera, dari situ akan menjadi suri tauladan. Dan ketika ada anak yang berprestasi diberikan rewad untuk memberikan stimulus kepada orang lain untuk meniru tindak kedisiplinan. ${ }^{10}$ Jadi proses pembiasaan penanaman sikap dan karakter, pemberian contoh dari guru maupun orang-orang yang telah berhasil, menerapkan aturan-aturan, serta

\footnotetext{
8 Wawancara dengan kepala sekolah SD Negeri Tanjunganom Banyuurip pada tanggal 30 November 2020

${ }^{9}$ Wawancara dengan guru kelas I SD Negeri Tanjunganom Banyuurip pada tanggal 30 November 2020

${ }^{10}$ Wawancara guru kelas VI SD Negeri Tanjunganom Banyuurip pada tanggal 30 November 2020
} 
STAINU Purworejo: Jurnal As Sibyan

Jurnal Kajian Kritis Pendidikan Islam

Vol 4 No 1 Januari - Juni 2021

dan Manajemen Pendidikan Dasar

Homepage: https://ejournal.stainupwr.ac.id/

Email: sibyan.stainupwrj@gmail.com

E-ISSN: : 2599-2732

pemberian sanksi kepada yang melanggar dapat menjadi strategi untuk guru dalam menanamkan sikap disiplin kepada siswanya.

Berdasarkan hasil olah wawancara peneliti melakukan pembukian melalui observasi pada tanggal 1 Desember 2020, setiap pagi siswa membaca doa sebelum pembelajaran dimulai dan setelah selesi pembelajaran di siang hari. ${ }^{11}$

Guru kelas II SD Negeri Tanjunganom berpendapat bahwa, menyampaikan secara langsung kepada anak agar anak bisa menanamkan sikap disiplin ${ }^{12}$ dijadikan sebagai strategi yang ia lakukan. Hal ini juga diterapkan oleh guru kelas kelas III SD Negeri Tanjunganom, strategi yang ia gunakan adalah dengan membuat peraturan diawal semester, menyampaikan secara lisan atau langsung, dan memberikan pengertian kepada siswa. Sedangkan guru kelas IV SD Negeri Tanjunganom menggunakan strategi ceramah dan juga menyampaikan aturan tata tertib sekolah dan memberikan sanksi bagi yang melanggar. ${ }^{13}$

Hal ini dapat disimpulkan bahwa penyampaian secara langsung banyak di jadikan strategi guru dalam menanamkan sikap disiplin kepada siswanya. Selain itu memberikan pengertian tentang aturan tata tertib sekolah dan sanksi apa yang akan diterima ketika ia langgar juga banyak diterapkan oleh guru.

Berdasarkan hasil olah wawancara peneliti melakukan pembukian melalui observasi pada tanggal 1 Desember 2020, terbukti ketika sedang dalam pembelajaran terdapat anak-anak yang berjalan-jalan guru langsung menegur anak tersebut dan menjelaskan bahwa ketika sedang pelajaran anak harus duduk mendengarkan dan tidak jalan-jalan. ${ }^{14}$

Kedisiplinan memiliki peranan yang sangat penting bagi setiap manusia. Kedisiplinan dapat membawa kita dalam keberhasilan di berbagai bidang. Karena setiap keberhasilan pasti terdapat kedisiplinan di dalam diri orang yang berhasil. Oleh sebab itu penting bagu guru memberikan pengertian kepada siswanya bahwa kedisiplinan sangat penting bagi masa depannya. Ada berbagai cara guru dalam

\footnotetext{
${ }^{11}$ Observasi pada tanggal 1 Desember 2020

${ }^{12}$ Wawancara guru kelas II SD Negeri Tanjunganom Banyuurip pada tanggal 30 November 2020

${ }^{13}$ Wawancara guru kelas IV SD Negeri Tanjunganom Banyuurip pada tanggal 30 November 2020

${ }^{14}$ Observasi pada tanggal 1 Desember 2020
} 
STAINU Purworejo: Jurnal As Sibyan

Jurnal Kajian Kritis Pendidikan Islam

Vol 4 No 1 Januari - Juni 2021

dan Manajemen Pendidikan Dasar

Homepage: https://ejournal.stainupwr.ac.id/

Email: sibyan.stainupwrj@gmail.com

E-ISSN: : 2599-2732

menyampaikan atau memberikan pengertian bahwa kedisiplinan itu sangat penting. Seperti pendapat guru kelas VI SD Negeri Tanjunganom, dicontohkan dengan anak yang sukses, ketika anak itu sukses maka kedisiplinan itu pasti ada. Jadi disini penanaman kedisiplinan dilakukan dengan pembiasaan seperti jadwal piket atau hal-hal yang wajib seperti pengerjaan tugas dan sebagainya. Jadi disini sedikit ada paksaan terkait kedisiplinan. ${ }^{15}$

Jadi dalam memberikan pengertian tentang pentingnya kedisiplinan dapat dilakukan dengan cara memberikan tanggung jawab kepada siswa itu sendiri, seperti pendapat guru kelas IV SD Negeri Tanjunganom, bahwa penanaman sikap disiplin itu penting dapat dilakukan dengan memberikan tanggung jawab kepada siswa, dan disaat-saat pembelajaran diberi arahan, misal sebagai siswa tugasnya adalah belajar dan tugas dari sekolah dan juga dari bapak ibu guru harus dijalankan dengan baik. ${ }^{16}$

Berdasarkan hasil olah wawancara peneliti melakukan pembukian melalui observasi pada tanggal 1 Desember 2020, terbukti setiap pagi dan pulang sekolah siswa yang mendapatkan tugas piket setiap pagi datang lebih awal untuk melaksanakan piket dan sebelum pulang juga melaksanakan piket. ${ }^{17}$

Guru kelas I SD Negeri Tanjunganom berpendapat bahwa, selalu mengingatkan kepada anak bahwa sikap disiplin akan membuat hidup teratur sesuai dengan aturan. Dengan disiplin yang tinggi seseorang bisa mencapai tujuan dan cita-cita. Jika tidak disiplin hidup akan menjadi kacau. ${ }^{18}$ Jadi kedisiplinan dapat menentukan bagaimana masa depan manusia itu sendiri, ketika seseorang berhasil maka disitu pasti terdapat kedisiplin. Dan ketika seseorang tidak berhasil maka orang tersebut tidak menanamkan sikap disiplin pada dirinya.

Menurut guru kelas V SD Negeri Tanjunganom bahwa penanaman sikap disiplin itu penting dapat dilakukan dengan menghubungkannya dengan kegiatan sehari-hari, menjelaskan kepada anak mengenai akibat ketika Ia tidak disiplin. ${ }^{19} \mathrm{Hal}$

\footnotetext{
${ }^{15}$ Wawancara guru kelas VI SD Negeri Tanjunganom Banyuurip pada tanggal 30 November 2020

${ }^{16}$ Wawancara guru kelas IV SD Negeri Tanjunganom Banyuurip pada tanggal 30 November 2020

${ }^{17}$ Observasi pada tanggal 1 Desember 2020

${ }^{18}$ Wawancara guru kelas I SD Negeri Tanjunganom Banyuurip pada tanggal 30 November 2020

${ }^{19}$ Wawancara guru kela V SD Negeri Tanjunganom Banyuurip pada tanggal 30 November 2020
} 
ini sama halnya dengan penanaman kebiasaan oleh siswa. Ketika ia sudah terbiasa melakukan kedisiplinan maka kedisiplinan sudah tertanam dalam dirinya. Serta pemberian pengertian tentang akibat dari ketidakdisiplinan akan membuat anak menjadi disiplin, karena ia tahu apa akibatnya ketika ia tidak disiplin.

Peraturan adalah sesuau yang sudah ditentukan dan harus dilaksanakan oleh semua anggota yang diberikan aturan tersebut. Segala aturan pasti ada sanksi atau hukuman jika tidak mematuhi aturan tersebut. Dalam lingkungan sekolah pasti sudah menerapkan sebuah aturan atau tata tertib sekolah. Tata tertib tersebut ditujukan kepada seluruh warga sekolah. sama halnya di SD Negeri Tanjunganom Banyuurip. Sekolah memiliki tata tertib sekolah yang ditujukan kepada guru, karyawan maupun siswanya. Dan setiap tata tertib ada sanksi-sanksi bagi yang melanggar.

Guru memiliki aturan sendiri untuk para siswanya. Terutama dalam hal kedisiplinan. Setiap aturan yang diterapkan juga terdapat sanksi tersendiri, seperti pendapat guru kelas IV SD Negeri Tanjunganom, ia menyatakan bahwa sanksi diberikan tergantung dari peraturan yang dilanggar, misal anak tidak mengerjakan PR, di sekolah diberi sanksi mengerjakan PR di luar kelas. ${ }^{20}$ Jadi setelah peraturan tersebut dibuat guru akan memberikan kesepakatan terlebih dahulu kepada anak tentang aturan dan sanksi yang akan diterima jika ia melanggar, seperti pendapat guru kelas V SD Negeri Tanjunganom, sebelumnya kita sudah membuat kesepakatan kepada anak. Jadi untuk pelanggaran apa sanksinya apa. ${ }^{21}$

Menurut guru kelas I SD Negeri Tanjunganom, sanksi diberikan tergantung dari kondisi anak dan sanksi apa yang ia langgar. Kita memberikan sanksi sesuai dengan kesalahan anak itu sendiri. ${ }^{22}$ Hal ini kondisi anak harus diperhatikan oleh guru. Alasan anak melanggar sebuah aturan harus terlebih dahulu diketahui oleh guru. Sebuah aturan yang diterapkan tidak semua siswa mampu mentaati karena alasan akademis maupun kondisik fisik siswa tersebut.

\footnotetext{
${ }^{20}$ Wawancara guru kelas IV SD Negeri Tanjunganom Banyuurip pada tanggal 30 November 2020

${ }^{21}$ Wawancara guru kelas V SD Negeri Tanjunganom Banyuurip pada tanggal 30 November 2020

${ }^{22}$ Wawancara guru kelas I SD Negeri Tanjunganom Banyuurip pada tanggal 30 November 2020
} 
STAINU Purworejo: Jurnal As Sibyan

Jurnal Kajian Kritis Pendidikan Islam

Vol 4 No 1 Januari - Juni 2021

dan Manajemen Pendidikan Dasar

Homepage: https://ejournal.stainupwr.ac.id/

Email: sibyan.stainupwrj@gmail.com

E-ISSN: : 2599-2732

Ada berbagai macam sanksi yang dapat diterapkan oleh guru seperti sanksi nasihat maupun teguran. Seperti pendapat guru kelas III SD Negeri Tanjunganom, bahwa ia menggunakan sanksi nasihat dan teguran, membersihkan kelas, tergantung dari kesalahan anak. Dan ia juga menerapkan aturan yang dimana kalau ada anak yang membuat anak lain menangis maka seluruh kelas akan menerima hukumannya. ${ }^{23}$

Berbeda dengan pendapat guru kelas II SD Negeri Tanjunganom, bahwa Ia tidak memberikan sanksi melainkan hanya menegurnya saja, karena Ia ingin anak tersebut memiliki kesadaran diri. ${ }^{24}$ Jadi kesadaran diri akan kedisiplinan juga penting untuk masa depan anak.

Selain memberi sanski yang sesuai dengan kesalahan anak dan kondisi anak, sanksi juga seharusnya diberikan untuk mendidik anak tersebut, jadi sanksi yang mendidik juga harus diterapkan oleh guru. Guru kelas VI SD Negeri Tanjunganom Banyuurip menyatakan bahwa, sanksi yang diberikan tentunya sanksi yang mendidik yang justru akan menguntungkan anak itu sendiri. Sebagai contoh anak tidak mengerjakan PR maka sanksinya adalah mengerjakan PR 2x. Dan disini tidak ada sanksi fisik baik pukulan atau lari, pushup itu tidak ada ataupun fisik berjemur di lapangan juga tidak ada, melainkan hukuman-hukuman yang bersifat mendidik. ${ }^{25}$

Pemberian sanksi kepada seseorang yang melanggar aturan dilakukan untuk memberikan efek jera bagi pelaku agar tidak mengulangi lagi kesalahan tersebut. Perubahan kepada anak yang diberikan sanksi ada berbagai macam sebab seperti pendapat guru kelas VI SD Negeri Tanjunganom, ada perubahan tetapi bukan karena lelah mengerjakan tugas melainkan karena malu terhadap temannya, karena namanya disebutkan di depan kelas karena membuat kesalahan. ${ }^{26}$ Seseorang dapat jera atas kesalahannya karena adanya rasa malu dalam dirinya. Ia malu karena kesalahan yang ia lakukan diketahui oleh orang lain.

\footnotetext{
${ }^{23}$ Wawancara guru kelas III SD Negeri Tanjunganom Banyuurip pada tanggal 30 November 2020

${ }^{24}$ Wawancara guru kelas II SD Negeri Tanjunganom Banyuurip pada tanggal 30 November 2020

${ }^{25}$ Wawancara guru kelas VI SD Negeri Tanjunganom Banyuurip pada tanggal 30 November 2020

${ }^{26}$ Wawancara guru kelas VI SD Negeri Tanjunganom Banyuurip pada tanggal 30 November 2020
} 
STAINU Purworejo: Jurnal As Sibyan

Jurnal Kajian Kritis Pendidikan Islam

Vol 4 No 1 Januari - Juni 2021

dan Manajemen Pendidikan Dasar

Homepage: https://ejournal.stainupwr.ac.id/

Email: sibyan.stainupwrj@gmail.com

E-ISSN: : 2599-2732

Selain itu guru kelas III SD Negeri Tanjunganom menyatakan bahwa, ada perubahan, seperti contohnya waktu itu ia memberi hukuman kepada anak yang mencoret-coret meja menggunakan tipex, lalu ia menyuruh anak tersebut untuk membersihkan meja tersebut hingga bersih, setelah itu tidak ada lagi anak yang berani mencoret-coret meja menggunakan tipex karena takun akan dihukum seperti anak tersebut. ${ }^{27}$ Jadi sanksi yang diberikan kepada salah satu anak dapat memberikan perubahan kepada orang lain yang melihatnya.

Pendapat berbeda disampaikan oleh guru kelas V SD Negeri Tanjunganom, ia menyatakan bahwa tidak semua siswa dapat jera dengan sanksi yang mereka dapatkan, karena latar belakang setiap siswa itu berbeda-beda. ${ }^{28}$ Hal ini berarti tergantung dari sikap yang sudah tertanam dalam siswa itu sendiri. Ketika ia sudah terbiasa dalam lingkungan masyarakat maupun keluarga tidak disiplin maka di sekolahpun akan sama dan sanksi yang diberikan kepadanya tidak akan membuat ia jera.

2. Kendala dan Pendukung dalam Meningkatkan Kedisiplinan Siswa SD Negeri Tanjunganom Banyuurip

a. Faktor penghambat

Ada berbagai kendala atau faktor penghambat dalam meningkatkan sedisiplinan siswa, seperti pendapat guru kelas III SD Negeri Tanjunganom, bahwa fator penghambatnya adalah siswa itu sendiri. ${ }^{29}$ Hal ini juga sependapat dengan guru kelas VI SD Negeri Tanjunganom bahwa, tergantung kondisi anak, kadang disiplin tidak bisa dilaksanakan seperti aturan dikarenakan ketidak mampuan anak baik dari faktor akademis maupun ekonomi. ${ }^{30}$ Setiap anak memiliki latar belakang dan kondisi yang berbeda-beda, terkadang anak memiliki ingatan yang tidak kuat atau pelupa, sehingga ia sering melanggar aturan yang telah diterapkan. Jadi siswa itu sendiri yang menjadi faktor penghambat dalam meningkatkan kedisiplinan.

\footnotetext{
${ }^{27}$ Wawancara guru kelas III SD Negeri Tnjunganom Banyuurip pada tanggal 30 November 2020

${ }^{28}$ Wawancara guru kelas V SD Negeri Tanjunganom Banyuurip pada tanggal 30 November 2020

${ }^{29}$ Wawancara guru kelas III SD Negeri Tanjunganom Banyuurip pada tanggal 30 November 2020

${ }^{30}$ Wawancara guru kelas VI SD Negeri Tanjunganom Banyuurip pada tanggal 30 November 2020
} 
STAINU Purworejo: Jurnal As Sibyan

Jurnal Kajian Kritis Pendidikan Islam

Vol 4 No 1 Januari - Juni 2021

dan Manajemen Pendidikan Dasar

Homepage: https://ejournal.stainupwr.ac.id/

Email: sibyan.stainupwrj@gmail.com

E-ISSN: : 2599-2732

Guru kelas I SD Negeri Tanjunganom berpendapat bahwa, faktor penghambatnya adalah kondisi siswa dan kondisi orang tua. ${ }^{31}$ Hal ini sependapat dengan guru guru kelas V SD Negeri Tanjunganom, bahwa faktor penghambatnya adalah latar belakang orang tua dan anak itu sendiri. ${ }^{32}$ Jadi yang menjadi faktor penghambat adalah siswa itu sendiri dan orang tua.

Guru kelas II SD Negeri Tanjunganom berpendapat bahwa yang menjadi faktor penghambat adalah keluarga, karena tidak semua anak tinggal dengan orang tua, melainkan dititipkan kepada kakek dan neneknya. ${ }^{33}$ Hal ini sependapat dengan guru kelas IV SD Negeri Tanjunganom, bahwa kurang perhatiannya keluarga terhadap anak, yang tidak bertanya mengenai PR maupun perlengkapan sekolah. ${ }^{34}$ jadi keluargalah yang menjadi faktor penghambat.

Berbeda dengan kepala sekolah yang berpendapat bahwa yang menjadi kendala atau faktor penghambat adalah terbatasnya waktu guru dengan siswa. Jadi guru tidak dapat memantau siswa setiap saat. ${ }^{35}$

Jadi dapat disimpulkan bahwa ada beberapa yang menjadi kendala atau faktor penghambat dalam meningkatkan kedisiplinan siswa antara lain: siswa itu sendiri, kondisi orang tua, keluarga, dan keterbatasan waktu antara guru dengan siswa.

\section{b. Faktor Pendukung}

Ada beberapa faktor yang dapat mendukung dalam meningkatkan kedisiplinan pada siswa. Seperti pendapat guru kelas VI SD Negeri Tanjunganom bahwa, yang menjadi faktor pendukung adalah guru itu sendiri yang harus selalu mengingatkan tentang hukum sanksinya, dan sarana prasarana seperti bentuk-bentuk sosialisasi perkumpulan wali siswa (parenting). ${ }^{36} \mathrm{Hal}$ ini berarti yang dapat mendukung dalam meningkatkan kedisiplinan adalah guru itu sendiri dan kerjasama dengan orang tua. Sependapat dengan guru kelas IV SD Negeri Tanjunganom bahwa, faktor yang

\footnotetext{
${ }^{31}$ Wawancara guru kelas I SD Negeri Tanjunganom Banyuurip pada tanggal 30 November 2020

${ }^{32}$ Wawancara guru kelas V SD Negeri Tanjunganom Banyuurip pada tanggal 30 November 2020

${ }^{33}$ Wawancara guru kelas II SD Negeri Tanjunganom Banyuurip pada tanggal 30 November 2020

${ }^{34}$ Wawancara guru kelas IV SD Negeri Tanjunganom Banyuurip pada tanggal 30 November 2020

${ }^{35}$ Wawancara kepala sekolah SD Negeri Tanjunganom Banyuurip pada tanggal 30 November 2020

${ }^{36}$ Wawancara guru kelas VI SD Negeri Tanjunganom Banyuurip pada tanggal 30 November 2020
} 
STAINU Purworejo: Jurnal As Sibyan

Jurnal Kajian Kritis Pendidikan Islam

Vol 4 No 1 Januari - Juni 2021

dan Manajemen Pendidikan Dasar

Homepage: https://ejournal.stainupwr.ac.id/

Email: sibyan.stainupwrj@gmail.com

E-ISSN: : 2599-2732

menjadi pendukung dalam meningkatkan kedisiplinan siswa adalah dukungan dari berbagai pihak seperti sekolah, guru, siswa dan orang tua, karena sekolah, baik guru sudah menanamkan sikap disiplinan tetapi tanpa ada dukungan dari orang tua yang di rumah maka tidak akan berhasil. ${ }^{37}$

Fasilitas yang mendukung dari sekolah juga berperan penting dalam meningkatkan kedisiplinan siswa seperti pendapat guru kelas III SD Negeri Tanjunganom bahwa fasilitas seperti rak sepatu dan tempat mencuci tangan dari sekolah juga berperan dalam meningkatkan kedisiplinan. ${ }^{38}$ Hal ini sependapat dengan guru kelas I SD Negeri Tanjunganom bahwa, Ada fasilitas, aturan yang berfasilitas, seperti di sekolah memfasilitasi rak sepatu agar anak disiplin untuk tidak menggunakan sepatu di dalam kelas, aturan dari guru, kerjasama orang tua. ${ }^{39}$ Hal ini berarti sekolah harus memberikan fasilitas yang memadai untuk mewujudkan tujuan dalam mendisiplinkan siswanya

\section{KESIMPULAN}

Guru sangat berperan penting dalam menanamkan sikap disiplin kepada siswanya. Guru menjadi sebuah contoh atau suritauladan bagi peserta didik di sekolah. Perilaku disiplin yang dilakukan oleh guru dapat memberikan contoh yang baik kepada siswa. Dalam menanamkan dan meningkatkan kedisiplinan siswa seorang guru memerlukan strategi. Berbagai strategi yang dilakukan oleh guru meliputi; Menjadikan guru sebagai suritauladan, Melakukan proses pembiasaan, Penyampaian secara langsung kepada anak, Pemberian pengertian kepada anak, Penerapan berbagai aturan oleh guru, Pemberian sanksi atau peringatan bagi yang melanggar, Pengajaran kepada anak tentang pentingnya mematuhi sebuah aturan.

Kendala dan faktor pendukung dalam meningkatkan kedisiplinan siswa SD Negeri Tanjunganom, antara lain: Kendala dalam meningkatkan kedisiplinan SD Negeri Tanjunganom meliputi; Kondisi siswa itu sendiri, Kondisi orang tua, Latar belakang keluarga, Waktu guru dengan siswa. Faktor pendukung dalam

\footnotetext{
${ }^{37}$ Wawancara guru kelas IV SD Negeri Tanjunganom Banyuurip pada tanggal 30 November 2020

${ }^{38}$ Wawancara guru kelas III SD Negeri Tanjunganom Banyuurip pada tanggal 30 November 2020

${ }^{39}$ Wawancara guru kelas I SD Negeri Tanjunganom Banyuurip pada tanggal 30 November 2020
} 
STAINU Purworejo: Jurnal As Sibyan

Jurnal Kajian Kritis Pendidikan Islam

Vol 4 No 1 Januari - Juni 2021

dan Manajemen Pendidikan Dasar

Homepage: https://ejournal.stainupwr.ac.id/

Email: sibyan.stainupwrj@gmail.com

E-ISSN: : 2599-2732

meningkatkan kedisiplinan meliputi; Sekolah, Fasilitas, Guru, Siswa dan Perhatian orang tua.

\section{DAFTAR PUSTAKA}

Aulina. Choirun Nisah. "Penanaman Disiplin Pada Anak Usia Dini”. Pedagogia, Volume 2 Nomor 1. 2017

Basrowi. Memahami Penelitian Kualitatif. Jakarta: PT Rineka Cipta. 2008

Canggih Kharisma, "peran guru dalam menanamkan karakter disiplin siswa di sekolah dasar negeri bleber 1 prambanan sleman", Fundamental Pendidikan Dasar, e-ISSN: 2614-1620 Vol. 1 No. 2.

Direktorat Pembinaan Pendidikan Anak Usia Dini Direktorat Jendral Pendidikan Anak Usia Dini Nonformal dan Informal Kementrian Pendidikan Nasional Tahun 2011

E. Mulyasa. Manajemen Pendidikan Karakter. Jakarta:PT Bumi Aksara. 2013

Ekosiswoyo. Rasdi dan Rachman, Manajemen Kelas. Semarang: IKIP Semarang Press. 2000

Khalsa, Sri Nam S. Pengajaran Disiplin dan Harga Diri. Jakarta: PT Indeks. 2008

Muhammad Anwar H. M. Menjadi Guru Profesional. Jakarta: Prenadamedia Group. 2018

Mursid. Belajar dan Pembelajaran PAUD. Bandung: PT Remaja Rosdakarya. 2015

Nurur Rohman. Peran Guru dalam Membentuk Sikap Disiplin Siswa Kelas V di MIN Jombang. Jombang: UIN Maulana Malik Ibrahim. 2019

Nurul Zuriah. Pendidikan Moral dan Budi Pekerti dalam Perspektif Perubahan. Jakarta: Bumi Aksara. 2011

Pusat Bahasa DEPDIKNAS. Kamus Besar Bahasa Indonesia. Jakarta: Balai Pustaka. Cet.3. 2007

Raisah Armayanti Nasution, "Penanaman Disiplin dan Kemandirian Anak Usia Dini dalam Metode Maria Montessori. Raudhah, Vol. 05, No. 02. 2017

Ramayulis. Ilmu Pendidikan Islam. Jakarta: Penerbit Kalam Mulia. 2002

Rusdiana dan Yeti Heryati. Pendidikan Profesi Keguruan Menjadi Guru Inspiratif dan Inovatif. Bandung: CV Pustaka Setia. 2015 
STAINU Purworejo: Jurnal As Sibyan

Jurnal Kajian Kritis Pendidikan Islam

Vol 4 No 1 Januari - Juni 2021

dan Manajemen Pendidikan Dasar

Homepage: https://ejournal.stainupwr.ac.id/

Email: sibyan.stainupwrj@gmail.com

E-ISSN: : 2599-2732

Sardiman A.M. Interaksi Motivasi Belajar Mengajar. Jakarta: PT. Raja Grafindo Persada. 2014

Sudarwan Danim. Pengembangan Profesi Guru. Jakarta: Kencana Media Grup. 2011

Sugiyono. Memahami Penelitian Kualitatif. Bandung: Penerbit Alfabeta. 2012

Suharsimi Arikunto. Manajemen Pengajaran Secara Manusiawi. Jakarta: Rineka Cipta. 2001

Umar Sidiq. Etika dan Profesi Keguruan. Tulungagung-Jatim: STAI Muhammadiyah Tulungagung. 2018

Undang-undang Nomor 20 tahun 2003 tentang system Pendidikan Nasional. Jakarta, pasal.40 ayat 1.2003

Undang-undang Republik Indonesia Nomor 14 tahun 2005 tentang Guru dan Dosen

(Bandung: Citra Umbara), pasal 20 ayat 1-5. 2016 